\title{
Renorming Labour Law: Can We Escape Labour Law's Recurring Regulatory Dilemmas?
}

Eric Tucker

Osgoode Hall Law School of York University, etucker@osgoode.yorku.ca

\section{Source Publication:}

Industrial Law Journal. Volume 39, Number 2 (2009-2010), p. 99-138.

Follow this and additional works at: https://digitalcommons.osgoode.yorku.ca/scholarly_works c) (1) $(9)$

This work is licensed under a Creative Commons Attribution-Noncommercial-No Derivative Works 4.0 License.

\section{Recommended Citation}

Tucker, Eric. "Renorming Labour Law: Can We Escape Labour Law's Recurring Regulatory Dilemmas?." Industrial Law Journal 39.2 (2009-2010): 99-138.

This Article is brought to you for free and open access by the Faculty Scholarship at Osgoode Digital Commons. It has been accepted for inclusion in Articles \& Book Chapters by an authorized administrator of Osgoode Digital Commons. 


\title{
Renorming Labour Law: Can We Escape Labour Law's Recurring Regulatory Dilemmas?
}

\author{
Eric Tucker
}

\author{
ABSTRACT
}

Historically, protective labour law pushed back against capitalist labour markets by facilitating workers' collective action and setting minimum employment standards based on social norms. Although the possibilities, limits and desirability of such a project were viewed differently in classical, Marxist and pluralist political economy, each perspective understood that the pursuit of protective labour law would produce recurring regulatory dilemmas requiring trade-offs between efficiency, equity and voice and/or between workers' and employers' interests. Recently, some scholars have argued that labour law needs to be renormed in ways that are market constituting rather than market constraining and that this change would avoid regulatory dilemmas. This article reviews the concept of regulatory dilemmas as formulated in the three major traditions of labour law scholarship, critically assesses recent work by Deakin and Wilkinson and by Hyde that proposes to renorm labour law and overcome regulatory dilemmas and proposes an alternative approach to understanding regulatory dilemmas based on the work of Wright.

\section{INTRODUCTION}

The concept of a regulatory dilemma is built on the model a zero-sum

\footnotetext{
* York University, email: etucker@ osgoode.yorku.ca
} 
game in which one party's interests or goals can only be advanced at the expense of another's. In the context of labour law, a regulatory dilemma typically arises when law that protects worker interests comes at the expense of employer interests although, as we shall see, it may also be articulated as a conflict between equity and voice on the one hand and efficiency on the other. The extent to which regulatory dilemmas are pervasive in labour and employment law and the reasons why they occur are the subjects of this article. ${ }^{1}$

There are widely divergent views on this topic. One view, developed by Karl Polanyi, is that labour law's regulatory dilemmas are recurring and are rooted in the contradictory position of labour in market societies. On the one hand, labour is bought and sold everyday in the labour market, thus confirming its commodity status. On the other, labour is unlike other commodities: it is not produced for the market, it cannot be stored and it cannot be separated from its bearer. Because of its ineradicable social and human character, it is a 'special' or 'fictive' commodity. Recurring dilemmas arise in protective labour law's efforts to navigate this contradictory position. When social formations allow labour to be treated as if it were purely a commodity, strictly through market ordering, dysfunctional social consequences result, which produce a movement to socially re-embed labour markets in ways that recognize and respond to its human character. This entails its partial decommodification. However, significant decommodification of labour will be met by opposing pressures brought by those who benefit from laissez-faire labour market policies. In short, the commodification/decommodification or protection/ liberalization dialectic is constant and ineradicable in market societies. Only in the context of a second great transformation, would the dialectic be resolved. ${ }^{2}$

Polanyi's formulation provides a helpful starting point, but it contains a number of ambiguities in regards to the dynamics of market societies and the possibility of creating stable embedded market economies. ${ }^{3}$ These matters are 
more precisely addressed in neo-classical and Marxist political economist frameworks that, despite their differences, both agree that within capitalist market economies, labour law, conceived as a protective and re-distributional project, will come at a cost either to economic efficiency (neo-classical economics) or to the ability of employers to advance their interests (Marxism). These costs are the source of recurring regulatory dilemmas, which will ultimately limit protective labour law's advance. A third framework, pluralist political economy, which also locates itself within capitalist market economies, takes a different approach that allows for positive compromises in which the interests of workers and employers are aligned so that protective labour law does not always come at the expense of efficiency or employer interests. However, pluralists also recognize that there is a limit to reform beyond which conflict will reappear and regulatory dilemmas will recur. Balanced trade-offs then become the prescribed order of the day.

Regulatory dilemmas have been sharply felt by supporters of workers' rights in the past several decades as a result of the rise of neo-liberalism, which has unleashed market forces at the expense of regulatory protection. Although marked by uneven development, the general trend has been toward a recommodification of labour achieved through a weakening of collective bargaining and minimum standards laws, both by formal amendment and by more indirect means. These include diminished enforcement and the promotion of economic policies that intensify competitive pressures on employers, leading many to pursue labour strategies that limit and sometimes violate their contractual and legal obligations to workers and that erode normative standards previously accepted in the labour market. This phenomenon has been aptly described in the North-American context as the 
gloves-off economy. ${ }^{4}$ These developments can be readily explained by the neoclassical and Marxist perspective, and may also be understood by disappointed pluralists on the basis that the space for positive gains through cooperation has been narrowed by processes of globalization and technological change. ${ }^{5}$

Given this rather dismal picture, it is not surprising that labour lawyers, particularly those operating within the pluralist frame, are particularly motivated to consider whether there are ways out of labour law's recurring dilemmas. Can labour law be renormed and reformed to provide a way to improve the quality of workers' lives within the constraints of capitalist market economies? Recently, several scholars have responded to this challenge by arguing that, indeed, there is a way forward. For example, inspired by Amartya Sen's work, Simon Deakin and Frank Wilkinson (D\&W) have advanced claims that by renorming labour law around the human capabilities approach a different agenda for labour law will emerge that can be implemented without running up against a conflicting commodification imperative. In a similar vein,Alan Hyde has applied game theory to argue that by renorming labour law around the goal of overcoming collective action problems that cause market failure we can both advance the goals of labour protection and redistribution without having to regulate against the market. $^{6}$

The goal of this intervention is 3-fold. First, I will more fully articulate the major formulations of labour law's recurring dilemmas. While the neoclassical argument is well known, I want to explore more deeply the classic Marxist account, which I think presents both a better explanation of regulatory dilemmas and a more troubling one for pluralists engaged in the renorming project. I also examine pluralist political economy, which can be seen as an attempt partially to liberate the project of protective labour law from 
the recurring dilemmas posited by neo-classical and classic Marxist political economy, while still acknowledging that protective labour law's ambitions are bounded by the need to balance competing demands for efficiency and protection. The second part of the paper will critically examine the renorming project, focusing on the work of D\&W and Hyde who, I argue, seek to advance the pluralist agenda by challenging the neo-classical account of regulatory dilemmas while largely ignoring the Marxist account. This leads them to express what I argue is an unfounded optimism about the possibilities of reconstructing markets without confronting the property and social relations that underlie actually existing capitalist labour markets. Hence, I argue there is a compelling need to bring capitalism back into the analysis.? In the third section, I attempt to begin such an account through a neoMarxist account of labour law's recurring regulatory dilemmas inspired by the work of Erik Olin Wright, which incorporates the insights of Marxist class analysis, game theory and neo-institutionalism to produce a more promising way to think about the dynamics of and possibilities for protective labour law within capitalist social formations. In the conclusion, I offer suggestions for further work on the project.

\section{LABOUR LAW'S RECURRING DILEMMAS IN (NEO)-CLASSICAL, CLASSIC MARXIST AND}

\section{PLURALIST POLITICAL ECONOMIES}

\section{A. (Neo)-Classical Political Economy}

Classical political economy begins from the premise that labour is a commodity. ${ }^{8}$ As Alchian and Allen put it in their economics text, under the 
heading, 'Labor Service is a Commodity', “Labor is not a commodity” is a battle cry of some labor groups. Whatever its emotional appeal, the assertion is misleading. Labor service is bought and sold daily'. ${ }^{9}$ From the perspective of classical political economy, the labour market is viewed as a realm of freedom and voluntarism in which profit seeking and willing buyers of labour service meet willing sellers seeking to maximize their income. They strike deals in their own best interest, constrained only by supply and demand curves. ${ }^{10}$

From this perspective, the price of labour, like all other commodities, reflects its economic cost. If wages fall below the standard of necessity for its reproduction, a shortage of labour relative to demand will result and wages will get bid up because of competition among buyers of labour service. If wages rise above the standard of necessity, a labour surplus will develop and wages will get bid back down due to competition among labour service sellers. This dynamic will keep wages, the price of labour, within the appropriate market-clearing range.

As well, because purchasers of labour service are profit maximizers, they will constantly be seeking to improve productivity by reducing the cost of inputs per unit of output. Increases in productivity can be achieved in a variety of ways, including the intensification of labour or the substitution of machinery for labour. If the costs of meeting the standard of necessity go down because of productivity increases, then, according to classical political economy, so too should the wages of workers since competition for jobs will increase as a result of decreased demand for labour service. However, a new equilibrium will be reached around the now diminished cost of the standard of necessity.

The smooth operation of the market is, of course, premised on perfect information and zero transaction costs, and although classical political economists acknowledge that real labour markets operate imperfectly, the 
imperfections are not viewed as so severe that they prevent the model from being a close enough approximation of actual labour markets to be of descriptive and prescriptive value.

What can cause disequilibrium, however, are non-market forces, one of which would be protective labour law that either facilitates collective bargaining that raises labour's bargaining leverage by reducing competition among individual sellers of labour power or sets minimum standards above market-clearing terms and conditions of employment. Both moves would grant labour a premium insofar as they would re-allocate to labour a greater share of socially produced wealth than its economic cost as determined by the market.

From the classical political economy perspective, however, either tactic would be counter productive. For example, if minimum wage laws raise wages above market clearing levels, the price of goods will increase resulting in a decrease in consumer demand, a reduction in production levels and unemployment (the scale effect). Alternatively, employers facing higher wage costs may substitute capital for labour (the substitution effect) in order to reduce production costs, again resulting in decreased employment. Since competition among workers cannot legally bid wages back down to market clearing levels, unemployment will persist. To use another example, laws that tolerate or foster workers' collective action, which reduces wage competition, will cause wages being bid up above their economic value, again resulting in unemployment either because of reduced demand or the substitution of capital for labour. The only difference here is that unemployment will increase competitive pressures and make it more difficult for labour to sustain quasimonopoly wages through collective action.

The above examples make labour law's regulatory dilemma stark and obvious. Labour law conceived of as a project to raise terms and conditions 
of employment above market clearing levels either by setting legally enforceable minimum standards or by strengthening workers' bargaining power through collective bargaining legislation necessarily produces unintended adverse effects that will be visited on some groups of workers whom the laws were intended to assist. Therefore, from the perspective of classical political economy, the only sensible project that labour law can pursue is to correct for market failures by, for example, providing labour market information to workers and employers, operating employment exchanges, etc. This view is depicted in Figure 1.

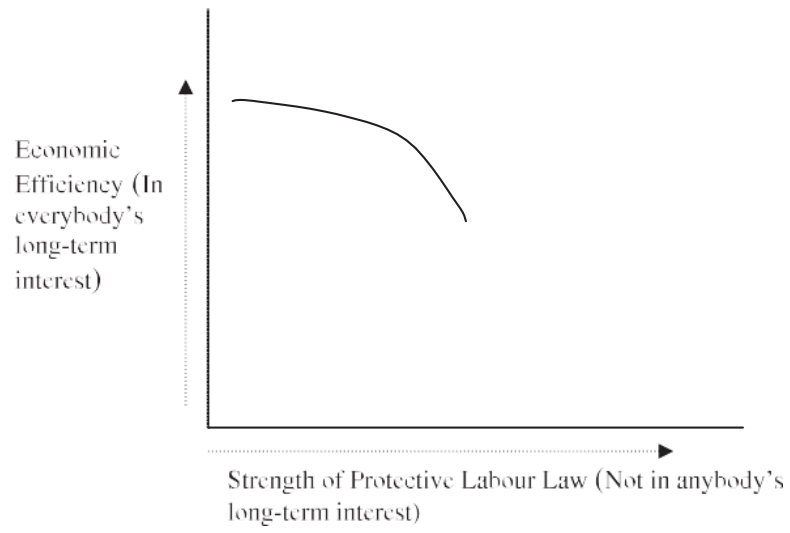

Figure 1. Neo-classical Model of Regulatory Dilemmas.

The line is curvilinear because it is assumed that minor protective and redistributive measures will be less efficiency impairing than stronger protective measures. It is also assumed that there will be a limit to protective labour law because as efficiency is increasingly impaired more workers, employers and consumers will suffer. As a result, protective labour law will become unpopular and unstable, and will be halted or rolled back since it was 
a mistaken policy to begin with, and one that only benefited a small number of labour market insiders at the expense of outsiders. Thus, the equilibrium point will tend to be in the upper left quadrant.

\section{B. Classic Marxist Political Economy}

The view of labour law's recurring dilemmas from Marxist political economy accepts some of the claims of classical political economy, but departs from it in fundamental ways. ${ }^{11}$ Marx understood that, from the perspective of capital, labour was indeed a commodity, not different in principle from a machine, which had to be purchased at its economic cost. ${ }^{12}$ However, unlike classical political economy which, at least in its more Malthusian moments, depended on population movements to respond to the over or under-supply of labour, Marx substituted the concept of the reserve army of labour - a relative population surplus. As Marx explained, faced with an increase in the demand for labour, capital could not wait for the population to increase to bring up the supply and bring wages back down. Rather, capital had the option of substituting capital for labour, thereby producing unemployment - a relative surplus population-that would increase competition among workers and reduce wages. Thus, for Marx, the reserve army of labour played a crucial role in keeping supply and demand 'on the right lines'. This analysis, however, remained entirely within the bounds of classical political economy. ${ }^{13}$

Unlike classical political economy, which portrayed the labour market as a realm of freedom, Marx had a very different analysis, based on the view that the commodification of labour within capitalism resulted in its 
exploitation and constituted a barrier to free human development. As a result, the gains that workers could hope to make within capitalism were limited; the achievement of human freedom required transformative change. It is to this other side of Marxist political economy, then, that we must turn to understand its theorization of recurring dilemmas.

Marx’s ontological starting point, expressed most clearly in his early works, is that of human beings having their own need for development, which they realize in nature and through social activity. 'Man is directly a natural being. As a natural being, and as a living natural being he is, on the one hand, endowed with natural powers and faculties, which exist in him as tendencies and abilities, as drives .... The objects of his drives exist outside himself as objects which are indispensable to the exercise and confirmation of his faculties'. ${ }^{14}$ For capital, and from the perspective of classical political economy, which treats workers as commodities, their humanity is denied. 'Political economy does not deal with him in his free time, as a human being, but leaves this aspect to the criminal law, doctors, religion, statistical tables, politics and the workhouse beadle'. ${ }^{15}$

Additionally, Marx went beyond classical political economy through his theory of surplus value, which he defined as the difference between the economic value of labour - its necessary cost of production — and the value produced by labour, which was appropriated by capital as profit. The extraction and appropriation of surplus labour by capital constituted the economic foundation of labour's exploitation. ${ }^{16}$

The commodification of labour and its exploitation under capitalism put labour and capital in fundamental conflict. On the one hand, capital's imperative to treat labour as a commodity is inconsistent with the labourer's need to develop him or herself as a rich multi-faceted human being. Workers, 
therefore, will resist their commodification. On the other hand, because social production yields a surplus, and because that creates the possibility for workers to raise their standard of living-to increase their level of necessity and human development-labour opposes capital's drive to appropriate that surplus for itself and seeks to increase its share. Thus, from within Marxist political economy, class struggle plays a central role in the degree to which work is humanized and in the definition and redefinition of workers' living standards, both of which significantly determine the scope for workers to develop themselves as full human beings.

These dynamics can be more closely examined by following the worker through the circuit of capital. For the propertyless worker, her own productive capacities cease to be use values since they cannot be exercised directly in the material world. They only have value when sold as commodities to those who own a means of production on which labour power can be productively employed. Thus, workers must enter into the sphere of exchange, the capitalist labour market, where as commodity sellers they find themselves in competition against each other. Moreover, propertyless workers operate in a buyers' market because of the reserve army of labour, which is constituted and retained by the ability of capital to substitute machinery for labour or to withdraw from the market entirely if the price of labour is driven too far upwards. Workers do not have the same substitution and exit options available to them, since they are deprived of access to alternative ways to secure a livelihood other than by the sale of their labour power and typically do not have the resources to sustain themselves and their families, let alone to flourish, while they stay out of the labour market. ${ }^{17}$ To offset this imbalance, workers must combine to reduce competition or to make the state their agency for overcoming their collective action problems, imposing 
minimum employment standards or providing social welfare that reduces their exclusive dependence on the labour market to gain access to the resources they need to sustain themselves. ${ }^{18}$

As the employer and the worker leave the labour market and enter the sphere of production, the workplace, the employer enters as owner of the worker's capacity to work, which he now has authority to deploy for the purposes of producing goods and services that can be realized on the market for a profit. ${ }^{19}$ The worker, of course, cannot be separated from the commodity labour power that has been sold, and so for the employer to extract use value from the commodity that he has purchased, the will of the worker must be subordinated to the will of the master. Production is organized to realize profit, not to satisfy the workers' need for development and self-realization. However, because workers are not simply commodities and have their own needs, they will push back to assert some control over the labour process. Yet here too struggle will occur on uneven terrain because of capital's greater economic freedom. To the extent that workers' resistance to their commodification in the production process conflicts with their employers' drive for profit, workers will only succeed through combination to reduce competition or the imposition of limits on their commodification at work through legally enforceable minimum standards.

Finally, the employer owns the products of labour, which exist for the capitalist as use values that have no use, but that must be sold as commodities for their value to be realized. For capital, the only use values that will be produced are those for which there is a reasonable expectation that they can be sold at a profit. Workers confront the products of their labour now as commodities, produced not for the purpose of satisfying their socially developed needs and wants, but for profitable sale. Needs that do 
not translate into effective demand-that is needs that are not backed by purchasing power-do not register on the market. Moreover, capital heavily invests in efforts to shape workers' needs in an effort to align their consumer 'choices' with the products they wish to sell. ${ }^{20}$ The linkages between sales driven consumption and human development become increasingly tenuous beyond a certain point and further reinforce workers' dependency on the sale of their capacity to work.

Thus, at each phase in the circuit of capital, the need of workers for selfdevelopment confronts the logic of capital, which seeks to reduce workers to commodity sellers in competition with each other, to exercise control over their productive capacities, to shape their needs and to appropriate for themselves the surplus value that is realized in the social process of production.

We will come back later to ask how, within this scheme, one can talk about capitalism as a system within which the development of human capabilities can be given priority, but for now we want to turn our attention to the implications of this analysis for a Marxist understanding of the recurring dilemmas for protective labour law, conceived of as a project to redistribute more of the socially produced wealth to labour and to humanize the production process, through the promotion of collective action or imposition of minimum standards.

As we have noted, Marxist political economy recognizes that workers are not reducible to commodities; that they can exercise agency and act as a class economically through combination and politically to use the state as an agency to facilitate collective action or to establish minimum standards higher than those that will be produced in a competitive labour market. But Marxist political economy also takes the view that the project of constructing 
protective and redistributive labour law will be resisted by capital. Labour pushes in one direction, capital in the other. Labour pushes to increase its standard of living by appropriating for itself a greater share of the socially produced wealth in order to satisfy its unmet need for development; capital pushes back to maintain or expand its rate of profit. Labour pushes to humanize work; capital pushes back if the result is a decrease in productivity, etc. But what determines where the line will be drawn? Is it a matter of supply and demand curves and market forces? How, if at all, does Marxist political economy differently theorize labour law's recurring dilemma from that of classical political economy?

Most fundamentally, Marxist political economy departs from classical political economy by putting workers' agency and humanity, their drive through class struggle to satisfy their unmet needs, at the centre of the story rather than a naturalized labour market which produces terms and conditions of employment based on the economic value of labour services. The labour market is viewed as a social institution produced and shaped by class struggle. The necessary costs to reproduce labour are not biologically determined (except perhaps in the last instance), but rather reflect the standard of living that workers have become accustomed to through previous struggles. Thus, in this account, there clearly is scope for protective labour law to operate outside the iron law of the market postulated by classical political economy, but it will depend on the balance of power between labour and capital.

That said Marx also recognized that the ability of labour to use the state to extract a greater share of socially produced wealth or to transform the labour process in a manner that better respected workers' needs for development was limited by the imbalance in class forces that is perpetuated 
by capitalism. That imbalance, as noted previously, is rooted structurally in capitalist property relations that create an asymmetrical dependency between labour and capital, which can also be translated into a greater ability to influence the state by virtue of capital's greater resources, fewer collective action problems and state dependency on the economy for resources. ${ }^{21}$

The resulting view of recurring dilemmas is depicted in Figure 2. It too assumes a curvilinear path on the assumption that modest protective labour laws that only lightly impinge on employers' interests will be easier to achieve than stronger laws, which will be more vigorously resisted by employers and thus will take increasingly more worker power to obtain. Moreover, it also assumes that within capitalism, there is a limit to the power that workers can obtain so that there is a structural limit to the reforms that can be achieved.

The Marxist view of recurring dilemmas is similar to that reached in classical political economy in that the dilemmas arise from the outset, are constant, and ultimately limiting in terms of what is possible. However, the dynamic is very different, because in Marxist political economy the strength of protective labour law at any given time depends on the balance of power between employers and workers, rather than economic efficiency and laws of supply and demand. This difference is important because it allows more scope for the development of protective labour law within capitalism than does classical political economy and because it contemplates that another world is both desirable and possible. However, within capitalism, the balance of power tilts in favour of employers and workers are engaged in an uphill battle. Each increment of labour protection will require marginally greater worker strength and the scope of labour protection that can be achieved within capitalism is, therefore, finite. 
This Marxist account of recurring dilemmas, however, is both classic and abstract. I will return later to consider a neo-Marxist account that arguably is better able to take into account the historically specific ways in which class power is institutionalized and to consider the possibility that under certain circumstances class cooperation can be in the mutual interests of labour and capital.

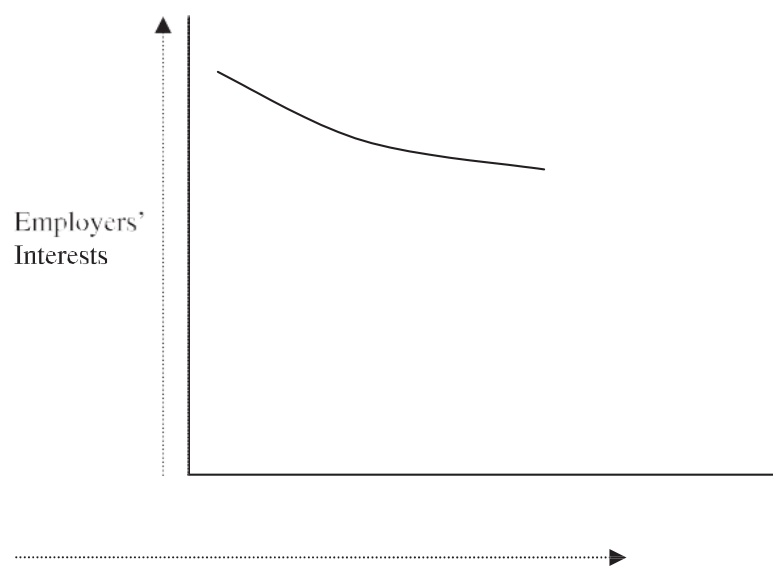

Workers' Power/Strength of Protective

Labour Law

Figure 2. Classic Marxist Model of Regulatory Dilemmas.

\section{Pluralist Political Economy}

The pluralist paradigm, or what I am calling pluralist political economy, is the third major framework for theorizing labour law's recurring dilemmas. This framework has exerted great influence on North American and English labour policy at various times, particularly in the post-World War II era, and continuing at least into the 1980s, when the neo-liberal approach (heir to classical political economy) became 
ascendant. As with the other two frames, there are numerous variations of pluralist political economy. Indeed, it is arguably the case that pluralism is more pluralistic in its theoretical commitments than the other frameworks we have examined ${ }^{22}$ and there are distinct differences between the English and the American pluralist traditions refl the very different paths of industrial relations policy development in the two countries.

The English variant of pluralism was developed in the work of Otto KahnFreund, Allan Flanders, Hugh Clegg and the early Alan Fox and was projected into the work and recommendations of the influential Donovan Commission (1965-68). ${ }^{23}$ Several common assumptions informed their approach. Industrial confl was accepted as being normal and legitimate, provided that it remained within certain limits; employers and unions exercised countervailing powers in the labour market so that collective bargaining could be counted upon to produce fair and mutually acceptable outcomes and the role of the state was to promote voluntary relationships and appropriate institutional arrangements rather than to legislate procedures or substantive outcomes. Given this view, the issue of recurring regulatory dilemmas did not figure prominently in the work of English pluralists, since the state's role was limited. In a balanced labour market with appropriate institutional arrangements, the common interests of employers and employees would advance together, albeit not without some marginal conflict over distributive concerns and work organization issues.

The North-American variant of industrial pluralism developed earlier, in the first two decades of the 20th century, as a conscious response to the neoclassical and Marxist approaches, by institutional economists, led by John R. Commons. ${ }^{24}$ Moreover, American industrial pluralism began to develop at a 
time when labour unions and collective bargaining had not been as well institutionalized as they had been in Great Britain and which ultimately required compulsory legislation, in the form of the Wagner Act, to become more fully established as a mechanism for regulating industrial relations. As well, the creation of a minimum standards regime for the unorganized was also seen as a necessary supplement to the collective bargaining regime. For these reasons, the theme of regulatory dilemmas was much more salient for North American than for British industrial pluralists, and so we will focus our attention on their work. However, the British turn toward more direct state involvement in labour market regulation since the Thatcher era makes this discussion directly relevant to their situation, as does the New Labour discourse on the compatibility of workplace fairness and economic efficiency and its emphasis on juridified collective bargaining and individual employment rights. $^{25}$

For the purposes of discussing North-American pluralism, it is useful to draw on an article by Budd, Gomez and Meltz that aims to provide a fully developed theoretical foundation for the pluralist industrial relations model: ${ }^{26}$

The fundamental theoretical assumptions of pluralist industrial relations are that (1) there is a conflict of interest in the employment relationship, (2) labor markets are not perfectly competitive, and (3) employees are human beings, not simply commodities or factors of production.

The contrast to classical political economy is obvious insofar as pluralists reject the view that labour is reducible to a commodity and that labour market outcomes are presumptively efficient or fair. If, as Bruce Kaufman has recently argued, labour markets only exist because of positive transaction costs, then the very assumption of near-zero transaction costs in neo-classical 
accounts of actually existing labour markets dissolves the basis for the existence of the institution they are studying. Once positive transaction costs and information asymmetries are recognized as the norm and not the exception, a claim that has ample support in institutional economics, then it becomes possible, indeed necessary, to examine the role of other institutions, including unions and protective labour law, in improving economic efficiency. ${ }^{27}$

What is less obvious from this statement of theoretical premises is the difference between pluralism and Marxist political economy, which arguably could also be said to embrace each of these three theoretical assumptions. The crucial disagreement is over the sources of conflicts of interest and the extent to which they can be reconciled through institutional adjustments. The pluralist perspective certainly recognizes conflicting or competing interests: workers want higher wages, job security and safe work, while employers want lower labour costs, flexibility and high output. ${ }^{28}$ Yet pluralists also emphasize that workers and employers have shared interests in productive workers, profitable employers and a healthy economy and that these common interests can be satisfied in a capitalist market economy.

Thus, it might be argued that, from a pluralist perspective, labour law's protective project-raising wages, providing job security, giving workers voice etc.- encounters a regulatory dilemma only when its effect is to reduce economic efficiency or impair employer profitability, and only then will hard choices have to be made about the trade-offs involved in pushing the project forward, maintaining the status quo or retreating. The crucial question is how much room is there for cooperation? A pessimistic pluralist would see relatively little scope for mutual gains and conclude that equity and efficiency trade-offs are the norm. This pessimistic view is depicted in Figure 3.

There is, however, a much more optimistic version of pluralism that sees 
far greater scope for mutual gains and thus pushes the point of conflicting interests, and the resulting recurring dilemmas it produces, deeper into the background. In part, this is achieved through the pluralists' precommitment to capitalist social relations. Unlike Marxist political economy, which interrogates the basis of workers' interest in these 'shared' goals, and roots them in their asymmetrical dependence on capital, pluralist political economy takes capitalist relations of

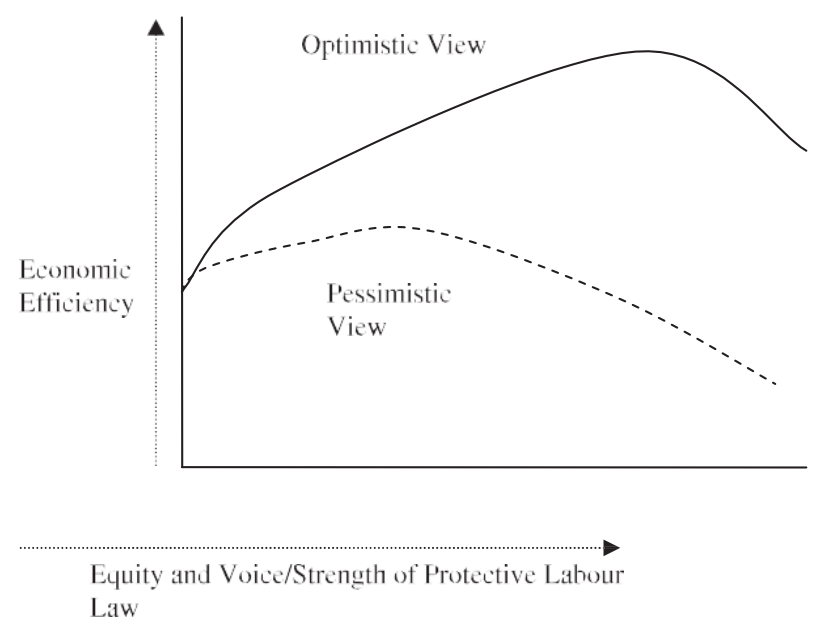

Figure 3. Pluralist Models of Regulatory Dilemmas.

production, at the very least, as a neutral fact of life, and more often as a positive foundation for the efficient production of goods and services. As a result, the material basis for conflict is minimized. Indeed, in most institutionalized forms of pluralism the pursuit of objectives that challenge capitalist relations of production is characterized as irresponsible, and not to be condoned. The goals of labour law are thus narrowed to objectives for 
which mutual gains are most likely to be available or at least conflict will be less fundamental. ${ }^{29}$

Not only do pluralists minimize the extent to which conflict is inherent in the employment relation, they identify another source for it: imperfectly competitive markets. These imperfections do not operate neutrally as between worker and employers, but rather systematically advantage employers by giving them quasimonopolistic power that is exercised to impose low wages and poor working conditions. 'From this theoretical perspective, laws and unions are viewed as mechanisms for levelling the playing field between employers and employees, thereby promoting the optimal operation of markets rather than interfering with it' ${ }^{30}$

This more optimistic version of pluralist political economy is premised on an empirical argument that taking workers' humanity into account and providing voice and equity enhances economic efficiency and, therefore, is in the interests not only of workers but also of employers, at both the microand macro levels. Thus high-performance work practices at the firm level and protective and redistributive labour law at the national level should be preferred by both employers and employees over their alternatives. This optimistic view is also presented in Figure 3.

At times, Budd et al.'s discussion of the optimistic version of a pluralist political economy seems to assume that the concept of recurring dilemmas has little or no place, as if the advancement of voice and equity is always efficiency enhancing. However, Budd et al. do not actually make this claim. Indeed, in his 2004 book, Budd explicitly states, 'The basic objectives of efficiency, equity, and voice can be complementary, but they often are in conflict' and in his coauthored 2009 book he goes further and states that they 'more often' clash. ${ }^{31}$ After all, if there were no conflicts between efficiency, equity and voice, then 
the very idea of balance would be redundant since all interests would run in the same direction. When and where these dilemmas occur and how they are resolved is another issue, but for present purposes the important point is that even within this optimistic version of pluralist political economy, while there is ample room for labour law's normative project to be realized in a manner that is consistent with economic efficiency and employers' interests, there is a limit to positive cooperation and beyond that point regulatory dilemmas will recur. ${ }^{32}$

\section{NEO-PLURALISM: RENORMING AND REFORMING LABOUR LAW FOR THE TWENTY-}

\section{FIRST CENTURY?}

This section begins by asking why it is that a number of scholars, particularly ones working in the pluralist tradition, are attempting at this juncture to redefine labour law's project. If the optimistic version of pluralist political economy was holding, presumably there would be little incentive for such a re-thinking. The common interests of employees and employers should have led to the establishment and stabilization a labour law regime within which humane workplaces that provided for equity and voice flourished in advanced capitalist economies generally, and especially in North America where pluralist prescriptions for state labour policy held considerable sway in the decades after World War II. Yet we know that the golden age of industrial relations, such as it was, has passed: income distributions have become increasingly unequal; ${ }^{33}$ and the share of the GDP that goes to wages has decreased while the share that goes to profits has increased. ${ }^{34}$ We also know that employers have increasingly resorted to a variety of forms of precarious employment, including temporary, part-time and self-employment, 
all of which have undermined the effectiveness of existing labour protection laws and undoubtedly have contributed to the trends described. ${ }^{35}$ While it is true that some employers have taken a higher road and adopted high-performance workplace models, the evidence on the benefits of this transition for workers is decidedly mixed. ${ }^{36}$

Even more important for this discussion is that in recent years protective labour law has utterly failed to sustain, let alone promote, collective representation. Trade union density, particularly in the private sector, has declined in most countries. ${ }^{37}$ In the USA, the collective bargaining legislation has ossified and employer violations of existing laws have become rampant, ${ }^{38}$ while in Canada labour law has been weakened, particularly as a result of the shift from card check to election-only certification procedures and ineffective remedies for employer unfair labour practices. ${ }^{39}$ As well, the North-American performance in regard to labour standards has been generally dismal, notwithstanding some advances in some places in the areas of occupational health and safety regulation and equity. ${ }^{40}$

The European story takes a somewhat different path, although the direction of change is much the same. Here the picture is less one of formal legal and institutional change (although not in the UK where the Thatcher government actively undermined collective bargaining to great effect), but rather one of more subtle and incremental alterations in the operation of institutions resulting from processes of defection, drift and legal reinterpretation that have produced increasing labour market dualism, weakening the collective bargaining and protective rights regime for the growing body of precarious workers, while often maintaining or even increasing protection for core workers. ${ }^{41}$

Overall, these findings do not pose a challenge to neo-classical and 
Marxist political economy. ${ }^{42}$ Rather, they are evidence that vindicates each perspective, albeit for different reasons. For neo-classical political economists, it is proof that the project of protective labour law is self-defeating to the extent that it is not efficiency enhancing and that profit-maximizing employers will find cheaper ways to produce if labour law attempts to drive up the cost of labour power above its economic value. For Marxist political economy, the findings reflect the shifts in class power and the success of capital's neo-liberal project of defeating the gains made by workers in the post-World War II period in order 'to re-establish the conditions for capital accumulation and to restore the power of economic elites' ${ }^{43}$ For pluralist political economy, however, not only are these developments socially undesirable; they may also signal that the space to achieve voice and equity without impairing efficiency is being narrowed and regulatory dilemmas are becoming sharper, leading some scholars who work in its tradition to reconsider the normative and empirical foundations of their project and its prescriptive implications.

These developments intersect and overlap with the emergence of a challenge to the traditional conception of labour law, conceived of as a project for counteracting inequality of bargaining power and to instead focus broadly on the economic and legal regulation of labour markets, without any strong prior commitment to the goals of protective regulation. As Hugh Collins noted, the strength of this alternative approach is that it expanded the scope of labour law to include a wide range of work arrangements and government policies that affect the supply and demand sides of the labour market, but its weakness is the loss of a vocational centre. ${ }^{44}$

The work examined below has been selected because it can be viewed both as a response to the crisis of the traditional protective model of labour law and as a continuation of the labour market regulation alternative, with both its 
strengths and weaknesses. The work is particularly interesting and important precisely because the authors embrace a progressive vision for the role of labour law within the confines of a largely untransformed political economy.

\section{A. D\&WandtheCapabilities Approach}

The Law of the Labour Market (LLM) is a fascinating and challenging book that ranges over a wide swath of labour history, policy and theory. In their final chapter, D\&W ask the question 'whether a means can be found for expressing the enduring values of labour law-including protection for the person and security of the individual worker and respect for the autonomy of collective organizations - within the framework of a market-based economic system'. Interestingly, what this formulation of the enduring values of labour law does not include is a reduction in unequal bargaining power or a more egalitarian redistribution of income and wealth to labour. ${ }^{45}$ As well, the authors do not name the market-based system within which labour law operates as capitalism. These omissions are neither accidental nor insignificant.

$\mathrm{D} \& \mathrm{~W}$ locate the challenges faced by labour law against the context of the neo-liberal agenda-whose effects they identify much as I have-and recognize the need to articulate a clear alternative. They explicitly reject older versions of the pluralist model, which cast the project of labour law as one of displacing or limiting market relations, particularly when the realization of its redistributive norms entails a right to an income above labour's market value. Instead, like a number of other labour lawyers, ${ }^{46} \mathrm{D} \& \mathrm{~W}$ adopt Amartya Sen's work on capabilities, most popularly presented in his 
Development as Freedom, ${ }^{47}$ and posit the central normative goal of labour law as institutionalizing 'forms of capabilities which provide individuals with the means to realize the potential of their resource endowments and thereby achieve a higher level of economic functioning'. ${ }^{48}$

Of course, renorming labour law around Sen's capabilities approach does not lead directly to any particular policy prescriptions, as D\&W recognize. ${ }^{49}$ Indeed, it might be argued that at this level of abstraction, the capabilities approach is as equally consistent with Marxist political economy as it is with pluralism. In fact, some scholars have noted the affinity between Sen's capabilities approach and the young Marx's ontology, which posits that human beings have an internal need to realize themselves in a plurality of dimensions and that they do so as social beings in their relations with others and the natural world..$^{50}$ However, for Marx, as we saw, capitalism simultaneously generates the opportunity for greater human richness and freedom, because of the increase in social wealth that it creates and constitutes a barrier to the realization of human richness and freedom for most of the population by separating workers from direct access to the means of production, thereby depriving them of the ability to experience their capacities as use values, requiring them to sell their capacities as commodities in competition with other sellers of labour service, etc. From this perspective, capitalism and the capitalist labour market are not realms of freedom in which workers can develop and realize their rich human capacities, but rather are sites of alienated labour in which workers' capabilities are limited by the profitmaximizing decisions of employers who mediate between workers and extract the benefits of social cooperation for themselves.

D\&W do not address the Marxist critique of capitalism and its implications for the capabilities approach. Indeed, the structural features of 
capitalism never appear as a relevant analytic consideration in D\&W's work. Rather their starting point is 'the idea that the labour market, like other markets, is a spontaneous order or self-governing system which ultimately rests on a set of mutually reinforcing conventions which are themselves the outcome of an evolutionary process'. ${ }^{51} \mathrm{D} \& \mathrm{~W}$ 's project, however, is not a Hayekian one insofar as they argue that there is ample scope for legal regulation and intervention in labour markets and that these formal measures can change the parameters within which market conventions evolve. However, they also want to avoid the trap of the previous generation of social rights and pluralist prescriptions, which were premised on an understanding that,to at least some non-trivial extent,protective and redistributive labour law pushed back against the market, so that its normative aspirations had to be balanced against efficiency concerns. ${ }^{52}$ The renorming of labour law around the capabilities approach transcends rather than reinforces the conflict famously noted by T. H. Marshall between social rights and a dynamic market economy $;^{53} \mathrm{D} \& \mathrm{~W}$ claim this is so because the capabilities approach involves reconstituting the market order in ways that improve its efficiency by converting individual resource endowments into capabilities that enable individuals to participate more effectively and freely in the market. In short, they make not only a normative or prescriptive argument about the desirability of renorming labour law around a market-based capabilities approach but a positive one as well: because the capabilities approach is market constituting and not market limiting, it can be realized without class conflict, provided that collective action problems can be overcome. This view is consistent with the third-way industrial relations policy proclaimed by the Blair government, encapsulated in the claim that 'efficiency and fairness are wholly compatible'. ${ }^{54}$ It is depicted in Figure 4. 


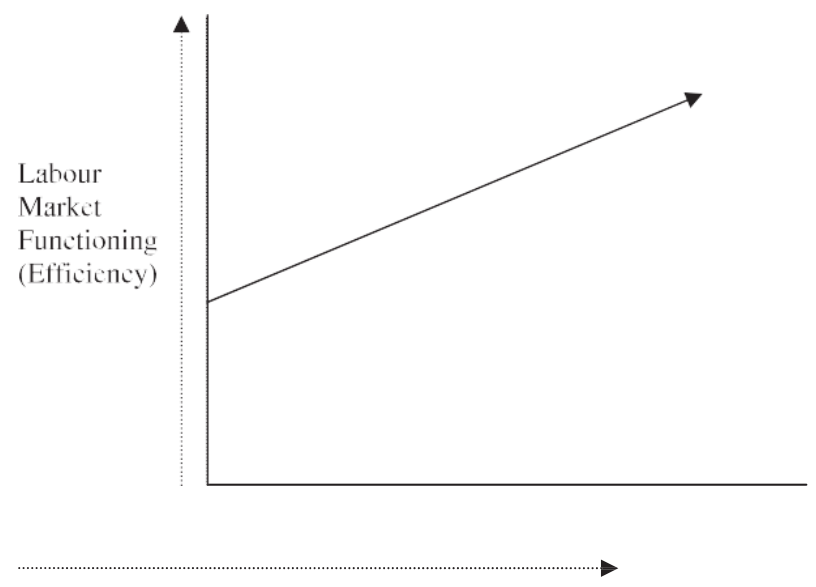

Strength of Laws Promoting the

Capabilities Approach

Figure 4. D\&W's View of the Capability Approach and Regulatory Dilemmas.

The renorming of labour law around a market-based capabilities approach is thus quite open-ended about the kinds of measures that it can justify. For example, in their discussion of the limits of spontaneous orders, D\&W ask whether a market order can function effectively 'in a situation in which there are large and enduring disparities in the wealth and resources of market participants? ${ }^{55} \mathrm{D} \& \mathrm{~W}$ reject the neo-classical answer that it can, and instead, build on an argument developed by Sugden who claims that redistribution 'is needed not to reverse the unpleasant results of the market, but rather to provide the preconditions for the market working in the first place'. From this perspective, D\&W suggest 'many of the redistributive and protective rules of labour law have a market-creating function'. ${ }^{56}$

The capabilities approach, however, is not invoked primarily to justify the 
traditional project of labour law, but rather to point toward a broader set of policies. Thus, later in their discussion, D\&W suggest that the capabilities approach could be achieved by the provision of some combination of social rights that guaranteed workers access to certain resources necessary to maintain a minimum standard of living and economic security (eg, sick pay, maternity pay, social welfare benefits) and to certain procedural rights ('rules governing workplace relations, collective bargaining and corporate governance'). ${ }^{57}$

The question to which I now want to return is whether D\&W's marketbased capabilities approach is likely to transcend the problem of recurring dilemmas because its prescriptions are not market limiting but market constituting and therefore will be in the interest of all market actors once collective action problems are overcome. It is here that D\&W's refusal to specify that they are not just dealing with a labour market but with a capitalist market becomes significant. Although the content of the capabilities approach may vary, it surely contains elements whose effect is to partially decommodify labour by giving workers a significant measure of market independence through state provision of social security, health care, education, etc. Similarly, even if the capabilities approach does not entail guaranteeing a final distribution of resources, but aims to increase effective market functioning by protecting workers' rights to engage in processes of collective bargaining or to participate in corporate governance, it substantively increases the bargaining power of labour relative to that of capital, at least compared to world in which no such rights are present and in which workers have not been able to achieve collective bargaining in the absence of state support. In the abstract, it is true that these measures can be described simply as ones that reconstitute the market on different terms. But can it be said that these measures do not push back against capitalist 
labour markets and, therefore, will not encounter resistance that will produce regulatory dilemmas?

One answer to the question is to say that these moves are not inconsistent with capitalism, but rather that they will produce a different variety of capitalism. Here it will be useful to turn briefly to the varieties of capitalism (VoC) literature, where the question of limits and dilemmas has been debated more thoroughly. The VoC approach, most fully articulated in Hall and Soskice, emphasizes the role of institutional arrangements in either facilitating or impeding the abilities of political-economic actors to coordinate among themselves and overcome collective action problems in order to engage in mutually beneficial cooperation. Institutional complementarities across different spheres of political economy produce two paradigmatic VoCs, coordinated market economies (CMEs) and liberal market economies (LMEs). One is not necessarily more economically successful than another, as each variety has its comparative advantages which can yield different paths to success. However, the way economic success is achieved and its benefits distributed, clearly has significance for the participants, with CMEs providing more social protection and higher living standards for workers. ${ }^{58}$ One can readily see the affi between a capabilities approach and CMEs and, indeed, it is largely within CMEs that a capabilities approach has had its greatest traction. ${ }^{59}$

Critics of the left have recognized the important contribution made by the institutionalists to an understanding of the dynamics of capitalism. '[I]t has always been a virtue of institutional political economy to demonstrate the salience of alternate institutional arrangements, and sociotechnical evolution, for the variable ways that capitalist exchange relations are grafted into social formations' ${ }^{60}$ However, they have also been sharply 
critical of its narrow focus on institutions to the virtual exclusion of political economic structure. For example, Jonas Pontusson has criticized the VoC approach for its emphasis on 'varieties' but its lack of attention to 'capitalism', which produces a focus in their work on issues of coordination and efficiency at the expense of consideration of conflicts of class interest and exercises of class power. ${ }^{61}$

This is not just a theoretical problem, according to Pontusson, but leads VoC theorists to understate the extent to which common structural pressures are pushing all advanced capitalist countries in the same directiontowards neoliberalism — notwithstanding the variations in their paths. Thus, for example, Pontusson points to general trends across both CMEs and LMEs towards reductions in social protection and unemployment insurance and growing labour market inequality. Moreover, he also argues that much of the variation that can be found across advanced capitalist countries is better explained by differences in working-class power, whether manifested in union density or political influence. ${ }^{62}$

There is ample evidence from other sources that supports Pontusson's general conclusions. The OECD recently reported that income inequality within OECD countries has been increasing at least since the mid-1980s in most countries, with big increases recently in Canada, Germany, Norway, USA, Italy and Finland.Although income poverty among the elderly fell, it increased among young families with children. Government spending from the mid1980s to the mid-1990s dampened the rise in poverty, but amplified it in the next decade, as benefits became less targeted on the poor. ${ }^{63}$

More recently, Wolfgang Streeck has written a compelling critique of the foundational assumptions of the VoC approach. Using the transformation of Germany, a key example of a CME, as his case study, Streeck demonstrates a 
clear trend toward disorganization and liberalization that has entailed the demise of institutions capable of subjecting economic actors to social obligations and public responsibilities, leaving them free to pursue profit maximization. This change, he argues, is not random, but rather is driven by the dynamics of capitalism in which resourceful capitalist actors are relentlessly driven by competition to undermine social constraints. According to Streeck, it is fundamentally misconceived to treat capitalism 'as a neutral apparatus for the joint production of shared prosperity'. ${ }^{64}$

For our purposes, the critique of $\mathrm{VoC}$ undermines the validity of the distinction that $\mathrm{D} \& \mathrm{~W}$ make between market constituting and market regulating. To paraphrase Streeck, it would be a mistake to view the labour market as a neutral apparatus that can be reconstituted to enhance capabilities without taking into account the specifically capitalist dynamics of contemporary labour markets and the likelihood of resistance and evasion by employers who are not driven to maximize social efficiency but rather profits. In short, what might be market constituting law in a social engineer's eyes, may very well be experienced as market regulating law for economic actors for whom such laws constitute a barrier to be overcome.

The salience of actually existing capitalism for the realization of the capabilities approach becomes even more apparent when we compare the social protection required to enhance capabilities with what is actually on offer. The relation between growing labour market flexibility and the provision of security has received a great deal of attention in Europe where the policy of promoting flexicurity, the combination of flexibility and security has been formally embraced. It is just the kind of policy that a market-based capabilities approach should support because it poses fl and security 'not ... as opposites, but as mutually supportive labour market components' ${ }^{65}$ Indeed, $\mathrm{fl}$ has been 
described 'as a political strategy [that] promises to make an end to the old confl between effi $\mathrm{y}$ and equity ${ }^{, 66}$ and, therefore, if realized, would bring an end to labour law's recurring dilemmas.

There is an immense literature on the subject of the implementation of flexicurity, and clearly it has been more successful in some countries (notably the Netherlands and Denmark) than in others. ${ }^{67}$ The vision of flexicurity ending trade-offs and recurring dilemmas, however, seems utopian. One recent empirical study found, that contrary to the goal of the flexicurity strategy, there is 'a positive correlation between aggregate flexibility and aggregate precariousness of work all over Europe. No country fulfils the flexicurity condition of high flexibility and low precariousness,${ }^{68}$ In the same forum, a European trade union researcher concluded that the European Commission's concept of flexicurity 'set flexibility above security, economic goals above social ones and employers' interests above those of workers'. ${ }^{69}$ Finally, a third study of flexicurity in Germany concluded that the best way to characterize recent reforms was as flexibility-security tradeoffs, with flexibility more strongly on the agenda than security. ${ }^{70}$ A preference for the promotion of competitive efficiency and the maintenance of high rates of employment over security will be particularly harmful to women who are disproportionately concentrated in precarious forms of employment. ${ }^{71}$ The point here is not that $\mathrm{D} \& \mathrm{~W}$ support these contemporary examples of flexicurity; they do not. Rather, it is that actually existing flexicurity practices provide further evidence that it is unhelpful to present capability-enhancing regulation as a neutral labour market constituting measure without taking into account the dominant practices of actually existing capitalist regimes, which favour flexibility for employers over security for workers, regardless of the form that security takes. Moreover, this approach diverts our attention away from the 
need for an analysis of the socioeconomic conditions under which greater worker security can be achieved.

Finally, we might ask about the compatibility of job quality and worker wellbeing, matters that also should be a central concern of the capabilities approach. A recent study by Francis Green presents a decidedly mixed assessment, noting that while in most developed capitalist nations wages and skill requirements have increased, there has also been widespread intensification of the work effort and a more mixed picture with regard to worker discretion. Green's overall assessment is that the quality of work life is strained and that the reason for this is that 'the employer's interest is to extract the best performance from workers, not to generate their maximum well-being'. He goes on to say that 'one has to hold to a very rosy ideology about capitalism' to accept a story that "in general the workplace is a "win-win" game, where what is good for workers is always right for the firm'. ${ }^{72}$

These observations are not intended to establish that rising income inequality is inevitable, that the flexicurity model must fail, that the quality of work life is bound to deteriorate or that the capabilities approach cannot or should not be pursued. Rather, they are made to challenge the claim of D\&W that conceiving of the capabilities approach as a market constituting strategy avoids the recurring regulatory dilemmas of protective and redistributive labour law. In short, this analysis suggests a second answer to the question posed earlier - that the reconstitution of markets according to the capabilities approach will, if pursued with any vigor, entail a pushing back against actually existing capitalist labour markets, built on definite social and property relations and a social logic of accumulation, which privileges the owners of the means of production over those who sell their labour power. 


\section{B. Alan Hyde: Renorming Labour Law around Collective Action Problems}

In a provocative article, Alan Hyde argued that labour law should be defined as 'the collection of regulatory techniques and values that are properly applied to any market that, if left unregulated, will reach socially suboptimum outcomes because economic actors are individuated and cannot overcome collective action problems'. ${ }^{73}$ In reaching this conclusion, Hyde explicitly rejects the view that labour law should be defined as the pursuit of values against the market, not because he does not care about normative values, but rather for pragmatic reasons; not only is there a lack of agreement over which non-market values should be pursued but also 'because one would expect employers to resist such humane, non-economic values strenuously, and for law to have major problems in efficacy.${ }^{74}$ In that sense, he might be viewed as a very pessimistic pluralist indeed. Although Hyde lists a number of market failures that characterize labour markets-including inelasticity of supply, collective action problems, low trust and opportunism that prevent the formation of efficient long-term contracts, inadequate incentives for investment in human capital and information asymmetries-most of these are addressed by overcoming collective action problems and so this becomes for Hyde the primary goal for labour law. Like D\&W, Hyde expressly stipulates that so conceived, labour law does not act against the market. 'When labour law addresses ... market failures, it does not stand against the market. It enables it' ${ }^{75}$ If true, the result of adopting such an approach would be to dissolve labour law's recurring regulatory dilemmas.

Hyde's project might be viewed as pluralism stripped of its normative goals of promoting voice and equity or redressing unequal bargaining power. 
In this regard, Hyde departs more radically from the pluralist tradition than D\&W who still posit a normative goal for the law of the labour market, the development of human capabilities. Hyde's labour law truly is reduced to a set of techniques for overcoming market failures, which like the pluralists, he presumably sees as being endemic in labour markets.

While Hyde would limit labour law to overcoming market failures, he does not embrace the neo-classical belief that the achievement of economic efficiency or Pareto-optimality is the ultimate objective of public policy. Indeed, he speaks more of the achievement of social optimality or social efficiency than he does of economic efficiency, but neither term is defined except as end states that could be achieved by the removal of the kinds of labour market failures he previously identified. In the abstract, labour market failures could favour employers and their removal would result in a worsening of work conditions, but presumably Hyde shares the view of pluralists that labour market failures disproportionately harm sellers of labour rather than buyers, so that overcoming market failure will produce more equity and voice, not less, even though that is no longer the explicitly stated vocation of labour law.

The basis for this belief is to be found in Hyde's use of game theory and, in particular, the stag hunt, in which the best outcome for both parties is to act cooperatively because any other strategy leaves both parties worse off. This argument is developed more fully in another paper where Hyde provides a gametheoretical defence of transnational labour standards. ${ }^{76}$ However, it is clear that regulatory dilemmas are only avoided if the model of the stag hunt applies. If not, then regulatory dilemmas recur. Thus, for Hyde the potential domain of labour law can be divided in two: 1) labour laws that regulate against the market and that produce severe regulatory dilemmas and 2) labour laws 
that overcome market failures to produce optimal outcomes for both parties and avoid regulatory dilemmas. This bifurcated view is captured in Figure 5.

The crucial question for those who care about justice for workers, as Hyde clearly does, ${ }^{77}$ is whether stag hunt games are the dominant paradigm of worker- employer interaction in capitalist labour markets. If, however, justice for workers is largely achieved by regulating against the market, then Hyde's switch to the stag hunt game is not worth the candle.

From an historical perspective, the claim that stag hunt games are the dominant model of worker-employer interaction seems implausible given the frequency and intensity of labour strife that has characterized most advanced capitalist countries. It is not hard to see why. Let us take the goal of overcoming workers' collective action problems. Presumably, Hyde would agree that historically this problem has been quite severe in most capitalist countries most of the time, and particularly so in LMEs like the United States and Canada. One reason why it has been so difficult for workers to organize is that, in most circumstances, employers have found that high levels of workingclass atomization leave them better off

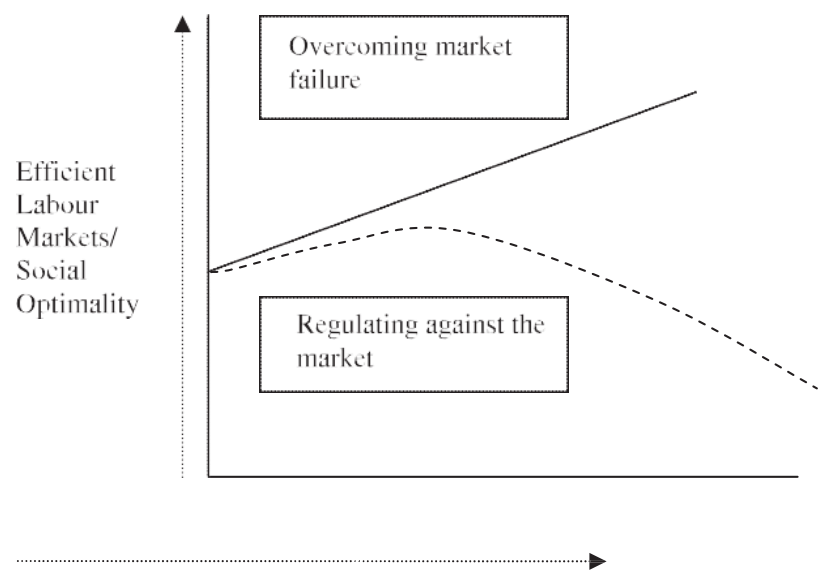


Figure 5. Hyde's Analysis of Labour Law's Recurring Regulatory Dilemmas.

economically than they would be if workers were well organized. This is because in capitalist labour markets employers can generally depend on competition between workers and the threat this poses to individual workers in order to obtain worker cooperation without having to make considerable concessions. As long as this condition holds, employer support for laws that assist workers in overcoming their collective action problems is unlikely to be forthcoming.

Hence, a renorming of labour law that makes overcoming workers' collective action problems a key objective, will be just as vigorously opposed by most employers most of the time as would a more traditional labour law regime that pursues non-market values, like fairness, voice and equality. Moreover, even if employer opposition to labour law promoting worker collective action did not prevent legislation from being enacted, it can be anticipated that it will be resisted, producing significant legal efficacy problems of the type described by Hyde in his critique of protective labour law. The history and recent trajectory of American collective bargaining would seem to provide ample evidence for this less optimistic view. ${ }^{78}$ Similarly, a recent study by Catherine Casey concluded that despite the aspiration in the European Union to achieve social citizenship, organizational democracy and citizen-worker participation in workplaces are being weakened by management's preference for flexibility, intensified work and decollectivized employment relations. ${ }^{79}$

In a more recent article that focuses on transnational labour standards, Hyde also advocates a renorming based on overcoming collective action 
problems in stag hunt games. ${ }^{80}$ Leaving aside the problem of moving from individuals to states and the assumption that states can be counted upon consistently to advance national long-term economic interests, rather than sectoral, class or even personal ones, ${ }^{81}$ what is significant for present purposes is Hyde's recognition that not much of a regulatory agenda can be generated for a transnational labour law renormed around stag hunts. ${ }^{82}$ Freedom of association comes off the table since Hyde recognizes that countries can potentially gain a competitive advantage through repressive labour laws. But what is left? Hyde's best two regulatory objectives for a renormed transnational law are the elimination of child labour and the promotion of strong occupational health and safety laws. But even here the evidence is not entirely convincing. Guy Davidov challenges Hyde's claim that child labour is never in the interest of developing country by arguing that lower labour costs associated with the use of child labour may indeed attract investment from the developed world. If that is the case, then it is not axiomatically true that the long-term benefit of sending young children to school will outweigh the shortterm benefit of attracting investment, and the international stag hunt around the elimination of child labour may not materialize. $^{83}$

The claim that no country gains a comparative advantage from lower occupational health and safety standards is arguably even weaker. The history of occupational health and safety regulation in Canada illustrates the point. When factory legislation was first proposed in the 1880 s (combining restrictions on child and female labour with general safety standards), Canadian manufacturers objected to measures that copied American and British standards on the ground that Canadian industries were much less well established and could not operate under the same restrictions without 
suffering serious damage. ${ }^{84}$ Put in modern parlance, they saw lower health and safety standards as necessary to give infant Canadian industry a competitive advantage over the more developed industries of the USA and England.

In sum, Hyde's proposal to renorm labour law around overcoming collective action problems in stag hunt games is extremely problematic. In order for this approach to produce a robust regulatory agenda, we have to make the problematic assumption that stag hunt games are characteristic of actually existing capitalist labour markets. Alternatively, if we drop that assumption for both national labour markets and international trade, then labour law is left with a very thin regulatory agenda indeed. Regulatory dilemmas are overcome by giving up on most of labour law.

\section{BRINGING CAPITALISM BACK IN: A NEO-MARXIST ACCOUNT OF LABOUR LAW'S} RECURRING RECULATORY DILEMMAS

It might be helpful to summarize the argument to this point. The concept of recurring regulatory dilemmas is central to the neo-classical, Marxist and pluralist theorizations of labour law, although each of these approaches has its own analysis of the reasons why regulatory dilemmas arise and the space for labour laws that avoid them. Arguably, that space has been narrowing since the 1980s, setting off a crisis in labour law. D\&W and Hyde have each tried to identify a new normative project for labour law that overcomes regulatory dilemmas by making it consistent with the operation of labour markets. In D\&W's case, the capabilities approach is said to meet this requirement because 
it is market constituting, while in Hyde's case consistency is met by limiting labour law to the goal of overcoming collective action problems caused by market failure. I have argued that the problem with both approaches is that they fail to give analytic salience to the structural dynamics of capitalism. While that might have been acceptable at a time when social democracy or Keynesian welfare states had partially succeeded in domesticating capitalism by putting it to work for social development, the resurgence of a more unbridled capitalism over the past 30 years or so no longer allows it to remain a background condition, assumed but without analytic significance. ${ }^{85}$ In D\&W's case, the failure to take into account actually existing capitalism results in an overly optimistic assessment of the prospects for advancing the capabilities agenda within a largely untransformed capitalist market economy, while in Hyde's case, at least when applied to national labour law, it leads to an unrealistic claim about the extent to which stag hunt games prevail in labour markets. ${ }^{86}$

The purpose of this section, then, is to suggest a way to bring capitalism back into the analysis of regulatory dilemmas, but do so in a way that invites rather than forecloses analysis of the historically specific conditions under which conflict and cooperation between labour and capital occurs in capitalist labour markets. The vehicle for this is an article by Erik Olin Wright on the theoretical foundations of class compromise, which has not received much attention in the labour law, industrial relations and political science literature on regulatory dilemmas and their resolution. ${ }^{87}$ In this section, I will present a summary of Wright's argument, apply it to the theme of regulatory dilemmas, and then argue that his model provides a more fruitful foundation for thinking about the dynamics of regulatory dilemmas and the spaces for overcoming them than do D\&W or Hyde.

Wright's central arguments are that within capitalism 'a positive class 
compromise-if it is achievable-will generally constitute the most advantageous context for the improvement of the life conditions of ordinary people' and that 'the possibilities for stable, positive class compromise generally hinge on the relationship between the associational power of the working class and the material interests of capitalists' ${ }^{88} \mathrm{He}$ proposes that instead of the constant inverse relationship between working-class interests and capitalists' interests postulated by classic Marxist theory, there is a curvilinear reverse-J relationship (See Figure 6). According to this model, capitalist-class interests are best satisfied when the working class is highly disorganized but if working-class associational power advances to a certain level, employers may find that their material interests are best advanced by cooperating with, rather than opposing worker collective action — although their interests would always be better served if working-class organization was returned to very low levels. Wright also argues that if working class organization were to increase even further to the point at which it had the capacity to threaten the right of capitalists to control the allocation of capital, the space for positive cooperation would disappear and employers would adopt an oppositional stance. When so extended, the cooperation curve exhibits a roller-coaster pattern that is principally shaped by the extent of working-class associational power and its impact on capitalist material interests.

Wright's account rests on a game-theoretic account of strategic interactions between workers and capitalists informed by a Marxist understanding of class power and interest. Wright identifies five possible strategic games and pay-offs for workers and capitalists. The games are the unilateral capitalist domination game, the conflict game, the prisoner's dilemma game, the assurance game (Hyde's stag hunt) and the unilateral worker domination game. As Wright notes, lurking 


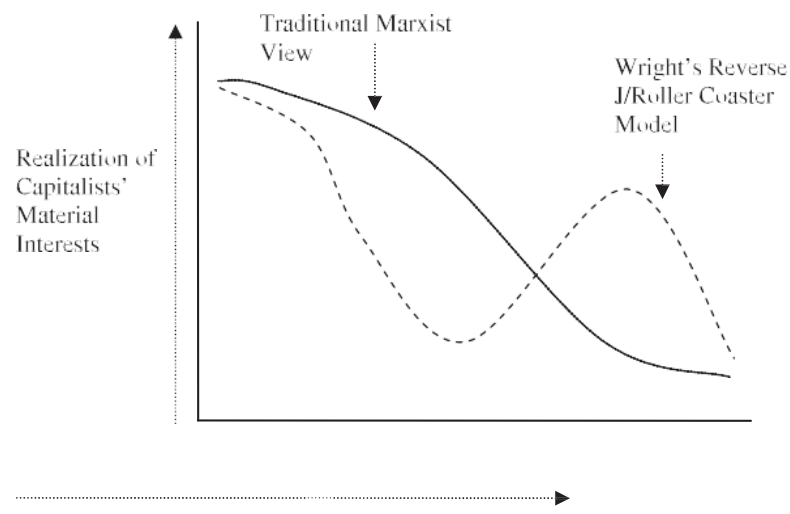

Strength of Working Class Organization

Figure 6. Traditional Marxist and Wright's Models of Class Cooperation.

in the background of the models is the problem of power and he hypothesizes that the impact of workers' associational power on employers' material interests can be thought of as determining which of these strategic games is going to be played. ${ }^{89}$ Thus, an employer domination game is played when weak workingclass organization enables employers to impose their will without the need to make concessions in order to obtain working-class cooperation. As working-class power increases, the game shifts to a pure conflict game, since workers now have the power to inflict material harm on employers if some of their demands are not met. This is the realm of negative class compromises in which labour gains come at the expense of capitalistclass interests. With further increases in working-class organization, the strategic environment can shift toward an iterated prisoner's dilemma game, in which there is room for positive class compromise in the spheres of politics, exchange and production. This occurs because worker organization may permit 
capitalists to overcome some of their collective action problems, allowing them to benefit from compromises made with working class organizations. The stability of the positive compromise will depend in part on the extent to which defectors can be detected and punished, which in turn may depend on the degree of working-class strength. A strict assurance game is theoretically possible, if the pay-off to both parties was greatest from mutual cooperation, but according to Wright this condition is unlikely to be reached in capitalist economies because employers are more likely to be better off in a world in which they do not have to make concessions to gain employee cooperation. However, there will be situations in which domination is not an available alternative and a class conflict game is too costly, leading the parties to cooperate. Even further increases in working-class power could push the game toward one of unilateral worker domination in which workers can impose their will on capital without needing its cooperation. At that point, the pay-off to capital for cooperation would drop sharply, and capital would be expected to fiercely resist any further erosion of its property rights, having nothing to lose but the chains being imposed on it.

Finally, Wright adds an additional layer of analysis by bringing in systemic and institutional constraints (Figure 7). Some results that might be possible based entirely on the level of worker associational power and its implications for employer interests become unattainable or more difficult to achieve as a result of systemic and institutional arrangements that have been created through previous rounds of conflict. Because these arrangements are the product of historical forces, they should not be viewed as fixed, and may indeed become the object of struggles for change, but their present existence creates a framework that shapes and limits to some degree the strategic options for each party. 


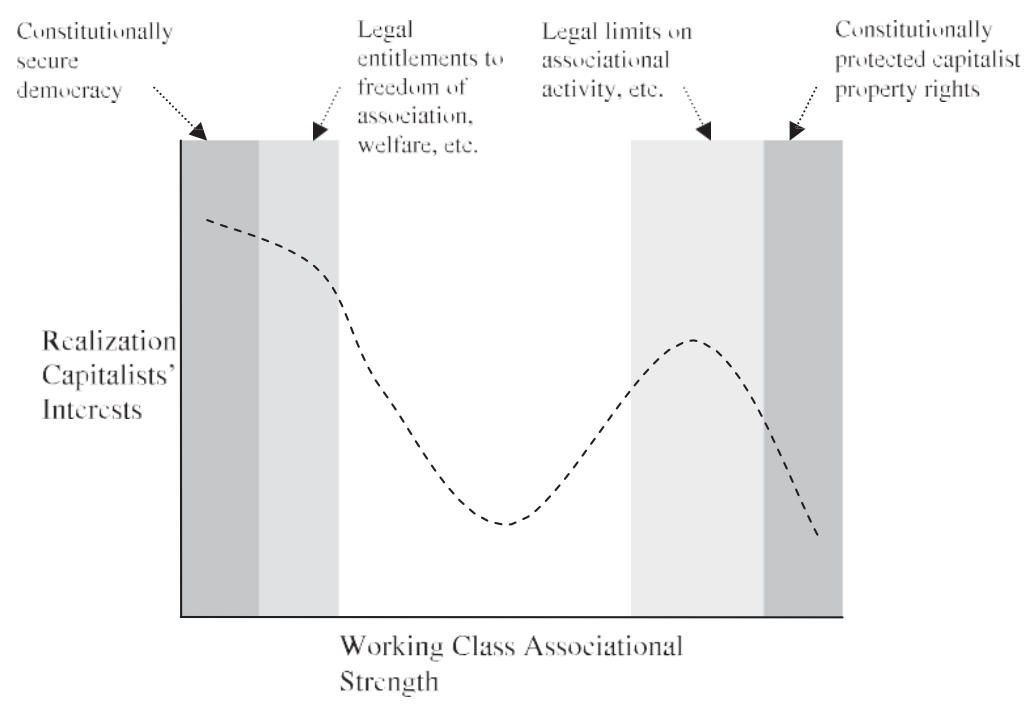

Figure 7. Wright's Model of Zones of Unattainability in Democratic Capitalism.

While Wright is concerned with the issue of class cooperation in the spheres of the labour market, production and politics, his model can be applied to regulatory dilemmas, which as we noted earlier are defined as a zero-sum games in which every gain for workers is accompanied by a corresponding loss for employers. From his theory, it could be hypothesized that in a world where workers had minimal associational power, particularly in the political sphere, regulatory dilemmas would not be much of an issue, since there would be little protective labour law. When workers' associational power increased to the point that labour could impose costs on employers, protective legislation would develop, but the regime would be characterized by recurring dilemmas, since each advance by workers would come at the 
expense of employers' material interests, with the outcome determined by the relative strength of the labour and capital. Finally, Wright's theory predicts that if the working class grew stronger, regulatory dilemmas could be overcome on condition that labour law not only protected workers but also assisted employers to overcome their collective action problems and so did not harm their material interests. However, the scope for such cooperation would be predicted to be limited and contingent, so that recurring regulatory dilemmas would be likely to re-emerge when employers saw the opportunity to obtain higher material outcomes by exiting, evading or dismantling the cooperative framework.

Wright's Marxist model arguably offers a better foundation for thinking about labour law's regulatory dilemmas and the conditions under which they can be resolved through positive compromise than either Hyde or D\&W. First, with regard to Hyde, we saw that the weakest link in his model was the unsupported assertion that the stag hunt game characterizes some significant portion of labour market interactions. The advantage of Wright's model is that it specifies a set of socio-economic conditions that determine which strategic game will likely be the dominant one and explains why in capitalist social formations stag hunt or assurance games are unlikely to emerge. While an empirical investigation of Wright's model is beyond the scope of this paper, there are numerous examples that lend support Wright's claim. Take for instance, the case of Canadian collective agreement extension legislation passed in several provinces in the 1930s. Basically, the law provided that the terms of a collective agreement could be imposed on all workers and employers in a particular industry in a particular region if it had acquired a predominant significance. In practice, this meant that agreements were only extended on the joint request of a union and major employers. Extension could 
serve the interests of labour by reducing wage competition in a world in which labour organization was weak and partial, but it could also serve the interests of employers by stabilizing the industry and reducing what was perceived to be harmful competition in a world in which barriers to entry were low and employer organization weak. The law facilitated a form of joint labour-management industrial regulation that operated to their mutual benefit and was used successfully for many years in a few industries, such as clothing manufacturing. In recent years, however, the scheme has been breaking down, particularly in sectors exposed to global competition where locally organized unions cannot help employers overcome their now much greater collective action problems. As a result, in some provinces the law has been weakened, while in others it has been repealed outright. ${ }^{90}$ Stories of similar nature can be told around the breakdown of centralized collective bargaining systems in many European countries. For example, sector-wide collective bargaining in Germany was sustained by cooperation between strong trade unions and employer associations where each party helped the other overcome its collective action problems and maintain solidarity and discipline. Since the 1980s, however, rising unemployment and international competition have altered the conditions that sustained mutual cooperation, leading to a breakdown of the system, leaving a shrinking core that is still covered and a growing periphery that is not. ${ }^{91}$

Wright's model also addresses a major weakness in D\&W's case, which is that it treats the labour market as an institution that can be socially engineered to improve its efficacy without taking into account the salience of class power and class interests. Wright's focus on class interests rather than on aggregate welfare is supported by the recent intervention of Hall and Thelen in the $\mathrm{VoC}$ literature, where they argue that the persistence of institutions does 
not depend primarily on how well institutions increase aggregate welfare, but rather on how institutions distribute costs and benefits and serve the interests of the relevant actors, which in capitalist political economies puts employer interests at the centre of the analysis. ${ }^{92}$ Whereas D\&W's positive case for a capabilities approach depends on the existence of a happy coincidence of the normatively desirable and the efficient, and on an unnamed agent capable of its enactment, Wright provides a model that begins to specify the socioeconomic conditions that need to be present for the realization of a marketbased capabilities approach that delivered benefits to workers. This analytic shift also entails a strategic shift from a politics premised on the existence of common interest to one based on the achievement of solidarities needed to challenge unequal power relations. ${ }^{93}$

Of course, like any model, Wright's presents an oversimplified view of the world. Moreover, given his particular objectives in that article, the model tends to present the relation between associational strength and the resolution of recurring dilemmas in a linear and static way. It is more useful-I think Wright would agree-to view the relation between workers' associational power and labour law dialectically, with the understanding that its current resolution is the product of past historical developments. One obvious implication of a dialectical approach is that the development of labour law has no predetermined destination or direction. Neither Wright nor most contemporary Marxists adhere to the view that the development of the forces of production will inevitably bring about a transformation of relations of production that strengthens workers' organizational capacity and their ability to domesticate capital. Labour law's regulatory dilemmas will not be necessarily resolved over time in ways that favour workers' interests. Indeed, as we noted, much of the current pessimism can be traced to the fact that the resolution of regulatory 
dilemmas is shifting to the figurative left (political right).

More importantly, a dialectical approach would require Wright's model to present a more complex view of the relationship between labour law and workers' associational power. In its present formulation, his model suggests that strong associational power should produce strong labour law, but we know that while historically this has been true some of the time (eg, the development of postWorld War II regimes), it is not true all the time (eg, the use of repression to restore the status quo ante that was challenged by labour demands and uprisings during and after World War I; conservative labour relations policy in the UK from 1979 to 1997). At the very least, the model would need to disaggregate the levels of workers' associational power in each of the spheres of the market, production and politics and consider the implications of the particular combinations of associational strengths and weaknesses for workers' ability to advance their interests in politics, as well as in market exchange and production.

Another concern is that the model suggests that there is a one-directional cause and effect relationship between associational power and labour law. However, looked at dialectically, there is a need to elaborate on the interactions between the two, understanding that strong labour law may provide an important foundation for establishing and maintaining workers' associational strength and that hostile laws may undermine the capacity of workers' to establish associational strength. This adds an element of dynamism to the model which in its present form works better for a static analysis of the existing moment. However, it is also important not to depart from the dialectic either to pose labour law as autonomous from associational strength and class power, as arguably D\&W's positive case for capabilities does, or to make the opposite mistake of denying any autonomy to labour 
law, or for that matter normative discourses regarding the appropriateness of particular outcomes. Indeed, the strength of D\&W's argument is arguably in the normative claims it makes for the capabilities approach rather than in its positive case for it as common-interest, market constituting regulation.

Finally, Wright's zones of attainability also need to be brought back into the dialectic. In the current model, they appear to be completely exogenous to associational strength and class power, limiting what is presently attainable. But again, if the focus shifts from a static to a dynamic analysis, then we need to more fully explore the creation of those zones as a product of past struggles and the possibility that they too become objects of contention leading to a shift in what is possible. Recent transformations of industrial relations systems in the UK, Germany and USA provide good examples of the ways in which outcomes which might at one point have been thought to be unattainable have been reclaimed as available ground by aggressive employer action in evading, avoiding and ultimately abandoning previously established legal and institutional constraints. ${ }^{94}$

\section{CONCLUSION}

The objective of this paper is to develop a better understanding of labour law's recurring regulatory dilemmas by clarifying how they have been theoretically constructed in three theoretical frameworks (neo-classical, Marxist and pluralist), by critically examining two recent attempts to overcome the problem of regulatory dilemmas by renorming labour law around capabilities $(\mathrm{D} \& \mathrm{~W})$ or collective action problems (Hunt) and by bringing back in a 
Marxist analysis of unequal power relations in capitalism (Wright) that does not preclude positive compromise as a way of resolving regulatory dilemmas. The paper's strongest claim is that those who wish to renorm labour law around a project that overcomes the regulatory dilemmas historically generated by labour law's traditional protective agenda and still generate a regime that is beneficial to workers' interests cannot do so by ignoring, marginalizing or naturalizing the property and social relations that characterize capitalist labour markets. 


\section{Notes}

${ }^{1}$ This article is only concerned with work performed in labour markets which is subject to labour and employment law. It implies no negative judgment about the value of reproductive labour performed outside labour markets.

${ }^{2}$ K. Polanyi, The Great Transformation (Boston, MA: Beacon Press, 1957; first published 1944). Also see G. Esping-Andersen, The Three Worlds of Welfare Capitalism (Princeton, NJ: Princeton University Press, 1990). For an insightful discussion of the unresolved dialectical tensions within market societies between liberalization and protectionism, see H. Lacher, 'The Slight Transformation: Contesting the Legacy of Karl Polanyi', in A. Buğra and K. Ağartan (eds), Reading Karl Polanyi for the Twenty-First Century (Basingstoke: Palgrave, 2007), 49-64.

${ }^{3}$ For a reading of Polanyi that identifies an epistemological break from Marxism and finds in his work support for the possibility of stable embedded market economies, see F. Block, 'Karl Polanyi and the Writing of The Great Transformation' (2003) 32 Theory and Society 275. For readings of Polanyi emphasizing his critical engagement with Marxist theory and belief in democratic socialism, see M. Burawoy, 'For a Sociological Marxism: The Complementary Convergence of Antonio Gramsci and Karl Polanyi' (2003) 31 Politics and Society 193 and Lacher, above n.2. Also, see G. Baum, Karl Polanyi: On Ethics and Economics (Montreal: McGill-Queen's University Press, 1996).

${ }^{4}$ A. Bernhardt et al. (eds), The Gloves-Off Economy: Workplace Standards at the Bottom of the American Economy (Champaign, IL: Labour and Employment Relations Association, 2008). For a helpful discussion of the subtler processes of institutional change, see K. Thelen, 'Institutional Change in Advanced Political Economies' (2009) 47 British Journal of Industrial Relations 471.

${ }^{5}$ For the latter, see H. W. Arthurs, The New Economy and the Demise of Industrial Citizenship (Kingston, ON: IRC Press, 1996).

${ }^{6}$ See below, ss 3 A \& B.

${ }^{7}$ W. Streeck, Re-Forming Capitalism (Oxford: Oxford University Press, 2009), Ch. 17, has recently made a similar intervention in respect of the institutional literature arguing that what is needed is a theory of capitalist institutional development.

${ }^{8}$ Classical political economy is not a single school of thought but rather contains within its traditions a range of views on various issues, among the most important being the theory of wages. A. Picchio, Social Reproduction: The Political Economy of The Labour Market (Cambridge: Cambridge University Press, 1992), 5-56, argues that there was a considerable difference between the views of Smith and Ricardo, who understood there was a social dimension to the determination of wages because the costs of producing labour were not determined biologically but on the basis of customary expectations about living standards, and later political economists, such as James Mill, Robert Torrens and J.R. McCulloch, who reversed the relationship and viewed wages as determined by supply and demand, which in turn established workers' living standards. My account of classical political economy draws more on its latter expression, and its subsequent development in contemporary micro-economic analysis. For a further discussion of the relation between classical and neo-classical economic analysis, see G. H. Hildebrand, 'The Labour Factor with the Classical and Neoclassical Systems of Economic Analysis', in C. Kerr and P. D. Staudohar (eds), Labor Economics and Industrial Relations (Cambridge, MA: Harvard University Press, 1994), 3-40.

${ }^{9}$ A.A.Alchian and W. R.Allen, University Economics, 3rd edn (Belmont, CA:Wadsworth Publishing, 1972), 407-8.

${ }^{10}$ The paradigm is so well-known, it hardly needs a source, but for a Canadian textbook version, see R. G. Ehrenberg, R. S. Smith and R. P. Chaykowski, Modern Labour Economics: Theory and Public Policy, Canadian edn (Toronto: Pearson, 2004), 44-57.

${ }^{11}$ As with classical political economy, Marxist political economy contains within it a number of different strains. My thinking about Marxist political economy has been heavily influenced by

M. Lebowitz, Beyond Capital, 2nd edn (Basingstoke: Palgrave, 2003).

${ }^{12}$ K. Marx, 'Economic and Philosophic Manuscripts (1844)', in T. B. Bottomore (ed), Early Writings (New York: McGraw-Hill, 1963), 76 ('It is self-evident that political economy treats the proletarian ... merely as a worker.... [H]e like a horse must receive as much as will enable him to work.').

${ }^{13}$ Lebowitz, above n.11, 107.

${ }^{14}$ Marx, above n.12, 207.

${ }^{15}$ Ibid, 76.

${ }^{16}$ For an alternative Marxist account of exploitation that does not depend on concept of surplus value, see E. O. Wright, Class Counts: Comparative Studies in Class Analysis (Cambridge: Cambridge University Press, 1997), 9-19, where he argues that exploitation exists when three criteria are satisfied:

1) the material welfare of exploiters depends upon reductions in the material welfare of the exploited;

2) the inverse interdependence of exploiters and exploited depends on the exclusion of the exploited from access to productive resources and 3) the exclusion generates material advantages to exploiters by enabling them to appropriate the labour effort of the exploited. 
${ }^{17}$ These are the conditions that satisfy Wright's definition of exploitation, ibid.

18 "For " "protection" against "the serpent of their agonies", the labourers must put their heads together, and, as a class, compel the passing of a law, an all-powerful social barrier that shall prevent the very workers from selling, by voluntary contract with capital, themselves and their families into slavery and death.’ K. Marx, Capital, vol 1, Part III, Ch. 10.

19 ' On leaving this sphere of simple circulation or of exchange of commodities, which furnishes the "Free-trader Vulgaris" with his views and ideas, and with the standard by which he judges a society based on capital and wages, we think we can perceive a change in the physiognomy of our dramatis personæ. He, who before was the money owner, now strides, in front as capitalist; the possessor of labour-power follows as his labourer. The one with an air of importance, smirking, intent on business; the other, timid and holding back, like one who is bringing his own hide to market and has nothing to expect but-a hiding'. Marx, above n.18, Part II, Ch. 6, 20.

${ }^{20}$ For a recent examination of the role of the sales effort and data on its enormous growth in the US economy, see R. W. McChesney et al., 'The Sales Effort and Monopoly Capitalism' (2009) 60 Monthly Review 1 (from 1920 to 2008 advertising expenditures increased nearly 10-fold while population increased about 3-fold).

${ }^{21}$ There is a vast literature on the capitalist state. For good overviews, see F. L. Block, Revising State Theory (Philadelphia, PA: Temple University Press, 1987) and M. Carnoy, The State and Political Theory (Princeton, NJ: Princeton University Press, 1984).

${ }^{22}$ R. Hyman, 'Pluralism, Procedural Consensus and Collective Bargaining' (1978) 16 British Journal of Industrial Relations 16, at 17 aptly refers to 'pluralism's pluralism'.

${ }^{23}$ For discussions of their work, see C. Howell, Trade Unions and the State (Princeton, NJ: Princeton University, 2005), 7-14; Hyman, above n.22; J.H. Goldthorpe, 'Industrial Relations in Great Britain: A Critique of Reformism' (1974) 4 Politics and Society 419.

${ }^{24}$ B. E. Kaufman, The Origins \& Evolution of the Field of Industrial Relations in the United States (Ithaca, NY: ILR Press, 1993); K. V. W. Stone, 'John R. Commons and the Origins of Legal Realism: or, the Other Tragedy of the Commons', in D. Hamilton and A. Brophy (eds), Transformations in American Legal History, vol 2 (Cambridge, MA: Harvard University Press, in press).

${ }^{25}$ Howell, above n.23, 174-90; S. Wood, 'From Voluntarism to Partnership: A Third Way Overview of the Public Policy Debate in British Industrial Relations', in H. Collins, P. Davies and R. Rideout (eds), Legal Regulation of the Employment Relation (Deventer: Kluwer, 2000), 111.

${ }^{26}$ J. W. Budd, R. Gomez and N. Meltz, 'Why Balance Is Best: The Pluralist Industrial Relations Paradigm of Balancing Competing Interests', in B. E. Kaufman (ed), Theoretical Perspectives on Work and the Employment Relationship (Champaign, IL: IRRA, 2004), 195, 199. Also, see J. W. Budd, Employment with a Human Face (Ithaca, NY: Cornell University Press, 2004) and S. F. Befort and J. W. Budd, Invisible Hands, Invisible Objectives (Palo Alto, CA: Stanford University Press, 2009), esp. Ch. 6.

${ }^{27}$ B. E. Kaufman, 'The Impossibility of a Perfectly Competitive Market' (2007) 31 Cambridge Journal of Economics 775; J. E. Stiglitz, 'Employment, Social Justice and Societal Well-Being' (2002) 141 International Labour Review 9. The institutional economics critique of neo-classical economics is vast. For a good overview, see S. Deakin and F. Wilkinson, 'Labour Law and Economic Theory: A Reappraisal', in Collins et al., above n.25, 29-62. For a Marxist critique of the efficiency claim, also based on information and transaction cost analysis, see S. Bowles and H. Gintis, 'Contested Exchange' (1990) 18 Politics and Society 165.

${ }^{28}$ Budd et al., above n.26, 200.

${ }^{29}$ Hyman, above n. 22, 32-3.

${ }^{30}$ Budd et al., above n.26, 201.

${ }^{31}$ Budd, 8 and Befort and Budd, above n.26, 122.

${ }^{32}$ C. Offe, 'The European Model of “Social” Capitalism: Can It Survive European Integration?', in M. Miller (ed), Worlds of Capitalism (London: Routledge, 2005), 146, makes a similar point in relation to European social capitalism (at 153): “"Too little" regulation will turn out to be as counter-productive in its consequences as "too much." There is no valid presumption of "the more the better".

${ }^{33}$ OECD, Growing Unequal?: Income Distribution and Poverty in OECD Countries (Paris: OECD, 2008); L. Osberg, A Quarter Century of Economic Inequality in Canada: 1981-2006 (Ottawa: CCPA, 2008), 720; E. Saez \& M. Veall, 'The Evolution of High Incomes in Northern America: Lessons from Canadian Evidence' (2005) 95 American Economic Review 831; T. Piketty and E. Saez, 'Income Inequality in the United States, 1913-1998' (2003) 118 Quarterly Journal of Economics 1.

${ }^{34}$ International Monetary Fund, World Economic Outlook: Spillovers and Cycles in the Global Economy (Washington, DC: IMF, 2007), 166-81; E. Russell and M. Dufour, Rising Profit Shares, Falling Wage Shares (Ottawa: CCPA, June 2007).

${ }^{35}$ G. Standing, Beyond the New Paternalism (London: Verso, 2002) and 'Labor Recommodification in the Global Transformation', in Reading Karl Polanyi, n.2 above, 67-93; L. Vosko (ed), Precarious Employment: Understanding Labour Market Insecurity in Canada (Montreal: McGill-Queen's 
University Press, 2006); D. Swank, C. J. Martin and K. Thelen, 'Institutional Change and the Politics of Social Solidarity in Advanced Capitalist Democracies' 2008-08-28 paper presented at the annual meeting of the APSA 2008 Annual Meeting, Hynes Convention Center, Boston, Massachusetts Online 2009-05-23 from http://www.allacademic.com/meta/p278562_index.html, Table 2.

${ }^{36}$ J. Goddard, 'A Critical Assessment of the High-Performance Paradigm' (2005) 42 British Journal of Industrial Relations 349; M. J. Handel and D. I. Levine, 'Editor's Introduction: The Effects of New Work Practices on Workers' (2004) 43 Industrial Relations 1. For some more recent positive assessments of the benefits of high performance work organization to workers, see P. Osterman, 'The Wage Effects of High Performance Work Organization in Manufacturing' (2006) 59 Industrial and Labour Relations Review 187; J. Goddard, 'Unions, Work Practices, and Wages Under Different Institutional Environments: The Case of Canada and England' (2007) 60 Industrial and Labor Relations Review 457.

${ }^{37}$ J. Visser, 'Union Membership Statistics in 24 Countries' (2006) Monthly Labor Review 38; R. Morisette, G. Schellenberg and A. Johnson, 'Diverging Trends in Unionization' (2005) Perspectives on Labour and Income 5.

${ }^{38}$ C. Estlund, 'The Ossification of American Labor Law' (2002) 102 Columbia Law Review 1527; J. Schmitt and B. Zipperer, Dropping the Ax: Illegal Firings During Union Election Campaigns (Washington, DC: Center for Economic and Policy Research, 2007).

${ }^{39}$ C. Riddell, 'Union Certification Success under Voting Versus Card-Check Procedures: Evidence From British Columbia, 1978-1998' (2004) 57 Industrial and Labor Relations Review 493; S. Slinn, 'No Right (to Organize) Without a Remedy: Evidence and Consequences of Failure to Provide Compensatory Remedies for Unfair Labour Practices in British Columbia' (2008) 53 McGill Law Journal 687.

${ }^{40}$ On employment standards, see Bernhardt et al., above n.4; M. P. Thomas, Regulating Flexibility: The Political Economy of Employment Standards (Montreal: McGill-Queen's University Press, 2009). On OHS, see E. Tucker, 'The Politics of Occupational Health and Safety in a Cold Climate: Diverging Trends in Worker Protection and Participation in Canada, 1985-2000' (2003) 58 Relations Industrielles/ Industrial Relations 395; S. Bisom-Rapp, 'What We Learn in Troubled Times: Deregulation and Safe Work in the New Economy' (in press) 55 Wayne Law Review.

${ }^{41}$ On the UK, see Howell, above n.23, Ch. 5. On continental Europe, see Thelen, above n.4, 487; M. Micheloti and C. Nyland, 'Varieties of Capitalism and Diversity in Labour Standards Regulation: The Case of Italy’ (2008) 14 European Journal of Industrial Relations 177.

${ }^{42}$ They do, however, suggest the need to take institutions more seriously as mediators of the underlying structural factors that dominate both frameworks.

${ }^{43}$ D. Harvey, A Brief History of Neoliberalism (Oxford: Oxford University Press, 2005), 19.

${ }^{44}$ H. Collins, 'Labour Law as a Vocation' (1989) 105 Law Quarterly Review 468. For a useful discussion of the breadth of issues that arise when the analytic focus moves from the firm-based employment relationship to the labour market, see J. Howe, R. Johnstone and R. Mitchell, 'Constituting and Regulating the Labour Market for Social and Economic Purposes', in C. Arup et al. (eds), Labour Law and Labour Market Regulation (Sydney: Federation Press, 2006), 307-21.

${ }^{45}$ This is not to say that the authors are uncritical of the inegalitarian tendencies of neo-liberal deregulation. In fact, they are and such concerns are raised earlier in LLM, particularly in Chs 3 and 4. Rather, the point here is that overcoming unequal bargaining power and achieving a more egalitarian distribution of income and wealth are not identified as central goals for the labour law reforms advocated in the final chapter.

${ }^{46}$ For example, see B. Langille, 'What Is International Labor Law For?' (2009) 3 Law \& Ethics of Human Rights 47, at 73-6.

${ }^{47}$ A. Sen, Development as Freedom (NewYork: Anchor Books, 2000).

${ }^{48}$ LLM, 347.

${ }^{49}$ LLM, 347.

${ }^{50}$ B. Biovanola, 'Personhood and Human Richness: Good and Well-Being in the Capability Approach and Beyond' (2005) 63 Review of Social Economy 249, at 263-5; V. Walsh, 'Smith after Sen' (2000) 12 Review of Political Economy 5, at 16 (who also notes the common Aristotelian roots of Marx, Smith and Sen). Sen himself makes the connection explicitly in a footnote in his Dewey Lectures. See A. Sen, 'Well-Being, Agency and Freedom' (1985) 82 Journal of Philosophy 169 at 202, fn 39.

${ }^{51}$ LLM, 277.

${ }^{52}$ This point is better developed in an earlier piece, J. Browne, S. Deakin and F.Wilkinson, 'Capabilities, Social Rights and European Market Integration', in R. Salais and R. Villeneuve (eds), Europe and the Politics of Capabilities (Cambridge: Cambridge University Press, 2004), 205-21. I am grateful to Judy Fudge for bringing this to my attention and to her insightful discussion of this aspect of D\&W's work in J. Fudge, 'The New Discourse of Labor Rights: From Social to Fundamental Rights?' (2007) 29 Comparative Labor Law \& Policy Journal 29. 
${ }^{53}$ LLM, 351.

${ }^{54}$ Department of Trade and Industry, Fairness at Work (London: HMSO, 1998) Cm 398, para 2.12. For a sympathetic discussion of this approach, see Wood, above n.25, 111. For a more critical view of the resulting policies, see C. Howell, 'Is There a Third Way for Industrial Relations?' (2004) 41 British Journal of Industrial Relations 1 .

${ }^{55}$ LLM, 284. Again, the radical implication of the question for a capitalist market order, which is premised on substantial disparities in wealth and income, is never considered.

${ }^{56}$ LLM, 284.

${ }^{57}$ LLM, 351.

${ }^{58}$ P. A. Hall and D. Soskice (eds), Varieties of Capitalism: The Institutional Foundations of Comparative Advantage (Oxford: Oxford University Press, 2001).

${ }^{59}$ Browne et al., above n.52.

${ }^{60}$ G. Albo, 'Contesting the "New Capitalism"', in D. Coates (ed), Varieties of Capitalism, Varieties of Approaches (Basingstoke: Palgrave, 2005), 63 at 72. Also, see H. Radice, 'Globalization and National Capitalisms: Theorizing Convergence and Differentiation' (2000) 7 Review of International Political Economy 719, at 722 ("First, capitalism is always an "institutionalized" order, in which the normal functioning of both exchange (markets) and command (hierarchies) requires that economic behaviour is "embedded" in institutions and practices'.)

${ }^{61}$ J. Pontusson, 'Varieties and Commonalities of Capitalism', in Coates, above n.60, 163 at 163-6. Also, see S. Strange, 'The Future of Global Capitalism: or, Will Divergence Persist for Ever?', in C. Crouch and W. Streeck (eds), Political Economy of Modern Capitalism: Mapping Convergence and Diversity (London: Sage, 1997), 182-91.

${ }^{62}$ Pontusson, above n.61, 174-85. Also, see Offe, above n.32, who argues on both political economic and institutional grounds that the triumph of negative integration makes it extremely unlikely that market constraining positive integration through a European-wide regime of social protection and security will be achieved through Open Market Coordination. Also, see Visser, above n.37, 46 who reports that union density in the European Union is on the same downward trajectory as the USA.

${ }^{63}$ OECD, Growing Unequal?: Income Distribution and Poverty in OECD Countries (Paris: OECD, 2008). Also see, G. Cornia, ed., Inequality, Growth and Poverty in an Era of Liberalization and Globalization (Oxford: Oxford Scholarship Online, 2008).

${ }^{64}$ Streeck, above n.7, 234.

${ }^{65}$ S. Bekker and T. Wilthagen, 'Europe's Pathways to Flexicurity: Lessons Presented from and to the Netherlands' (2008) Intereconomics 68.

${ }^{66}$ H. Jørgensen and P. K. Madsen, 'Flexicurity and Beyond-Reflections on the Nature and Future of a Political Celebrity', in Jørgensen and Madsen (eds), Flexicurity and Beyond (Copenhagen: DJØF Publishing, 2007), 7-8.

${ }^{67}$ For a recent overview, see E. Viebrock and J. Clasen, 'Flexicurity and Welfare Reform' (2009) 7 Socio-Economic Review 305.

${ }^{68}$ A.Tangian, 'Is Europe Ready for Flexicurity? Empirical Evidence, Critical Remarks and a Reform Proposal' (2008) Intereconomics 99 at 105.

${ }^{69}$ M. Keune, 'Flexicurity: a Contested Concept at the Core of the European Labour Market Debate' (2008) Intereconomics 92 at 98.

${ }^{70}$ J. Leschke, G. Schmid and D. Griga, 'On the Marriage of Flexibility and Security: Lessons from the Hartz reforms in Germany’, in Jørgensen and Madsen (eds), above n.66, 335 at 360. The paper also contains an excellent conceptual model for thinking about the ways flexibility and security could be combined.

${ }^{71}$ D. Ashiagbor, 'Promoting Precariousness? The Response of the EU Employment Policies to Precarious Work', in J. Fudge and R. Owens (eds), Precarious Work, Women, and the New Economy (Oxford: Hart Publishing, 2006), 79. In the same volume, also see K. Rittich, 'Rights, Risk, and Reward: Governance Norms in the International Order and the Problem of Precarious Work', 31 and L. Vosko, 'Gender, Precarious Work, and the International Labour Code: The Ghost in the ILO Closet', 53. An even more recent study of six European countries found that flexible (non-standard) employment was increasing, especially among women and the young, but that there were significant gaps in most national social protection regimes. See K. S. Buschoff and P. Protsch, '(A-)Typical and (In-)Secure? Social Protection and "Non-Standard” Forms of Employment in Europe' (2008) 61 International Social Security Review 51 .

${ }^{72}$ F. Green, Demanding Work (Princeton, NJ: Princeton University Press, 2006), 166-7.

${ }^{73}$ A. Hyde, 'What Is Labour Law?', in G. Davidov and B. Langille (eds), Boundaries and Frontiers in Labour Law (Oxford: Hart Publishing, 2006), 37 at 53.

${ }^{74}$ Ibid, 58.

${ }^{75}$ Ibid, 54 .

${ }^{76}$ Ibid, 55-8. Also see A. Hyde, 'A Game Theory Account and Defence of Transnational Labour 
Standards-A Preliminary Look at the Problem', in J. D. R. Craig and S. Michael Lynk, Globalization and the Future of Labour Law (Cambridge: Cambridge University Press, 2006), 143.

${ }^{77}$ For example, see A. Hyde, 'Who Speaks for the Working Poor?: A Preliminary Look at the Emerging Tetralogy of Representation of Low-Wage Service Workers' (2004) 13 Cornell Journal of Law and Public Policy 599.

${ }^{78}$ For a recent study demonstrating that American employer opposition to collective bargaining reform has been greater than for other labour law reforms, see D. Weil, 'Might Monolith or Fractured Federation? Business Opposition and the Enactment of Workplace Legislation', in Bernhardt et al., above n.4, 287.

${ }^{79}$ C. Casey, 'Organizations, Workers, and Learning: New Prospects for Citizenship and Work?' (2009) 13 Citizenship Studies 171.

${ }^{80}$ A. Hyde, 'The International Labor Organization in the Stag Hunt for Global Labor Rights' (2009) 3 Law \& Ethics of Human Rights 153.

${ }^{81}$ Streeck, above n.7, 172-86.

${ }^{82}$ For a more utopian application of Hyde's model to transnational labour law, see Langille, above n. 46,47 .

${ }^{83}$ G. Davidov, 'Comment on Alan Hyde: The Perils of Economic Justifications for International Labor Standards' (2009) 3 Law \& Ethics of Human Rights 179.

${ }^{84}$ E. Tucker, Administering Danger in the Workplace: The Law and Politics of Occupational Health and Safety Regulation in Ontario, 1850-1914 (Toronto: University of Toronto Press, 1990), 82-101.

${ }^{85}$ Streeck, above n.7, 233-6.

${ }^{86}$ When Hyde applies this norm to transnational law he concedes that it leaves a very limited regulatory agenda.

${ }^{87}$ E. O. Wright, 'Working-Class Power, Capital-Class Interests, and Class Compromise' (2000) 105 American Journal of Sociology 957.

${ }^{88}$ Ibid, 958.

${ }^{89}$ Ibid, 974.

${ }^{90}$ For example, on Quebec, see G. Vallée and J. Charest, 'Globalization and the Transformation of State Regulation of Labour: The Case of Recent Amendments to the Quebec Collective Agreement Decrees Act' (2001) 17 International Journal of Comparative Labour Law and Industrial Relations 79. In Ontario, the collective agreement extension scheme was repealed by a neo-liberal Conservative government in 2000 (S.O. 2000, c. 41, s 144(5).)

${ }^{91}$ Streeck, above n. 7, 38-55, 136-46.

${ }^{92}$ P.A. Hall and K. Thelen, 'Institutional Change in Varieties of Capitalism' (2009) 7 Socio-Economic Review 7.

${ }^{93}$ P. Tamabaki, 'From Citizenship to Human Rights: The Stakes for Democracy' (2009) 13 Citizenship Studies 3, makes this point in the context of a discussion of the dangers of trying to make universal human rights the driving force behind progressive politics.

${ }^{94}$ On the UK, see Howell, above n.23, 131-93; on Germany, see Streeck, above n.7; on the USA, see Bernhardt et al., above n.4. 